\title{
Geospatial Modeling for Sinkholes Hazard Map Based on GIS \& RS Data
}

\author{
Omar Al-Kouri ${ }^{1}$, A'kif Al-Fugara ${ }^{2 *}$, Samih Al-Rawashdeh ${ }^{3}$, Balqies Sadoun ${ }^{3}$, Biswajeet Pradhan ${ }^{4}$ \\ ${ }^{1}$ Department of Human Sciences and Technology, Community College, Taibah University, Medina, Kingdom of Saudi Arabia \\ ${ }^{2}$ Surveying Engineering Department, Faculty of Engineering, Al al-Bayt University, Mafraq, Jordan \\ ${ }^{3}$ Surveying and Geomatics Engineering, Faculty of Engineering, Salt, Jordan \\ ${ }^{4}$ Department of Civil Engineering, Faculty of Engineering, University Putra Malaysia, Serdang, Malaysia \\ Email: okouri@gmail.com, ${ }^{*}$ dr.akifmohd@yahoo.com,rsamih@hotmail.com, biswajeet24@gmail.com
}

Received August 6, 2013; revised September 6, 2013; accepted September 13, 2013

Copyright (C) 2013 Omar Al-Kouri et al. This is an open access article distributed under the Creative Commons Attribution License, which permits unrestricted use, distribution, and reproduction in any medium, provided the original work is properly cited.

\begin{abstract}
The Kinta Valley is an area of karst in the north-western part of Peninsular Malaysia. Over 30 years of uncontrolled land use and development has led to significant changes in topography and geomorphology, such as the appearance of sinkholes. In this paper, geospatial techniques were utilized to the task of evaluating sinkholes susceptibility map using a spatial multi criteria evaluation approach (SMCE). Sinkhole location and a spatial database were applied to calculate eight inherent causative factors for limestone instability namely: lithology, structure (lineament), soil cover, slope, land use mining, urban area features, ponds and rivers. The preparation of the sinkhole geohazard map involved summing the weighted values for each hazard element, which permits the construction of geohazard model; the results of the analysis were validated using the previous actual sinkholes locations in the study area. The spatial distribution of sinkholes occurrence, urban development, faults distribution and ex-mining ponds are factors that are directly responsible for all sinkholes subsidence hazards. Further, the resulting geo-hazard map shows that $93 \%$ of recent sinkholes occur in areas where the model flags as "high" and "very high" potential hazard, located in the urbanized part of the valley, while less-developed areas to the west and southwest suffered less sinkhole development. The results can be used for hazard prevention and land-use planning.
\end{abstract}

Keywords: Geo-Hazard Mapping; Karst; Sinkholes; Geospatial Modeling

\section{Introduction}

Urban development is rapidly occurring in the karstic terrain of the Kinta Valley, Malaysia. Sinkholes are an inherent feature of the landscape; they present hazards and engineering challenges to the development of infrastructure. Sinkhole hazard is common in limestone karst, associated with subcircular surface depression or collapse structure formed by the collapse of small subterranean karst cavities [1-3]. The annual sinkhole hazard potential in a given area may be estimated using Equation (1):

$$
\mathrm{R}=\sum \mathrm{H} * \mathrm{E} * \mathrm{~V}
$$

where $\mathrm{R}$ is the potential hazard, expressed in terms of victims per year or financial losses per year; $\mathrm{H}$ is the hazard; $\mathrm{E}$ is the exposure or elements at potential hazard,

${ }^{*}$ Corresponding author. referring to the population and the economic value of the properties and activities that may be affected by sinkholes; and V is the vulnerability, given by the unitary fraction of the exposure that is expected to be damaged if affected by a sinkhole. The total annual potential hazard corresponds to the sum of the estimated potential hazard for each exposed human element. Preferably, the hazard should include two components: the probability of sinkhole occurrence and the expected severity of the future sinkholes [4].

"Reference [5]" quantifies bedrock geology, depth to bedrock, sinkhole density, and distances to the nearest sinkhole in southeastern Minnesota but potential controlling factors such as structural control, topographic settings, human activities, and land-use are not yet built into the model. "Reference [6]" conducted a comparable study to produce a sinkhole density map of 385 sinkholes in the Forest City Quadrangle of Central Florida. This 
map was used to evaluate applications for sinkhole hazard prediction, and was further extended to construct sinkhole-risk models used in sinkhole risk assessment due to the lack of data coverage. "Reference [7]" studied the phenomena of sinkholes along the eastern part of the Dead Sea using 2D multi electrodes resistivity imagining that a lot of recent sinkholes were interpreted.

The environmental conditions most commonly thought to control sinkhole morphometry are the underlying geology, including bedrock, fractures and faults, soil depth to bedrock, and local hydrology [8,9]. There is a need to develop a more detailed karst map by identifying and ranking factors that control the morphometry of mapped sinkhole formations. Spatial technology has been used intensively to study and map aspects of karst areas. "Reference [10]" studied the environmental impact of sinkholes in Dead Sea area. "Reference [11]" constructed a sinkhole probability map based on various parameters such as sinkhole distribution, bedrock geology, depth to bedrock, and nearest-neighbor analysis. "Reference [12]" suggested that sinkhole clustering occurs because such zones had similar geologic and topographic characteristics favoring sinkholes formation. Various mapping techniques that had been applied to the study of landslides had been modified for the study of sinkhole development [13].

As a natural phenomenon, the occurrence of sinkhole is controlled basically by geological conditions, morphological conditions, land cover conditions, etc. The sinkhole susceptibility analysis can give a clue of the dangerous degree by site. In this context, space borne satellite images have been largely used in the environmental related studies [14-16]. Karst terrain is very difficult to map. Sinkholes are the most common karst features mapped because they are an indicator of bedrock dissolution, and they can be recognized on topographic maps or through remote sensing techniques [5]. "Reference [17]" located sinkholes through stereoscopic viewing of panchromatic aerial photography and plotted them on 1:24,000 scale topographic maps. "Reference [17]" primarily relied on these remote sensing techniques, but also performed some field check where sinkhole locations were questionable.

The use of a GIS permits the integration of the data from various sources and on different topics more accurately and faster than the traditional analytical methods. GIS applications enable researchers to objectively identify the conditions that trigger karst hazards. However, karst formations develop in very specific ways that are influenced by the unique local conditions of the area [18]. Local climate, geology, and urban development all affect the evolution of karst formations [19]. This study demonstrates the utility of computer visualization and geographic information system (GIS) software to develop a more detailed karst map for Kinta valley region to assist in future planning initiatives.

\section{Study Area Location}

The Kinta Valley is located approximately at latitude $4.60^{\circ} \mathrm{N}$, longitude $101.07^{\circ} \mathrm{E}$, lies to the west of the Main Range of the Peninsular Malaysia, and east of the Kledang Range, in the state of Perak, Malaysia (Figure 1). It is under laid by limestone of Devonian to Permian age. The topography reflects typical mature tropical karst with scattered steep-sided limestone hills protruding throughout the flat-lying valley. Only about $23 \%$ of the limestone occurs as hills, while the rest is an over laid by the alluvium [20]. Since it is sandwiched between two granitic highlands, so it provides 1) constant water supply, 2) lowland, scattered wet areas?, 3) swampy areas. Swampy areas are believed to be a factor of high rate of karstification.

\section{Materials and Methodology Used}

\subsection{Data Collection and Analysis Concept}

The data used in this study comprise of remotely sensed imageries and relevant ancillary data. The imageries acquired by SPOT 5 and LandSat 5 satellites over the study area, were collected from the Malaysian Centre for Remote Sensing (MACRES); Spot5 images on March 27, 2005 while LandSat 5 images in 2000. Aerial photography of the study area and its surrounding, acquired in 1981 and 2004, were collected from the Department of Survey and Mapping (JUPEM). The images provided information on karst surface features and facilitated the process of field investigations, especially when identifying surface features across large landscapes. Soil and land use maps (2000) of the study area were provided by the Department of Agriculture, Malaysia. The spatial data were geo-coded to conform to the Malaysian Rectified Skew Orthomorphic (RSO) projection and then converted to GIS format for multi-criteria analysis.

\subsection{Data Pre-Processing}

Prior to implementation of the automatic edge detection processing to map lineaments, SPOT 5 and Landsat TM data were enhanced and then geometrically corrected. Geometric errors were corrected using sensor characteristics and ephemeris data include scan skew, mirror-scan velocity variance, panoramic distortion, platform velocity, and perspective geometry. Visual screen digitizing of lineaments were done after performing proper image enhancements using the appropriate filters.

\subsection{Image Enhancement}

Image enhancement techniques were used to produce the 


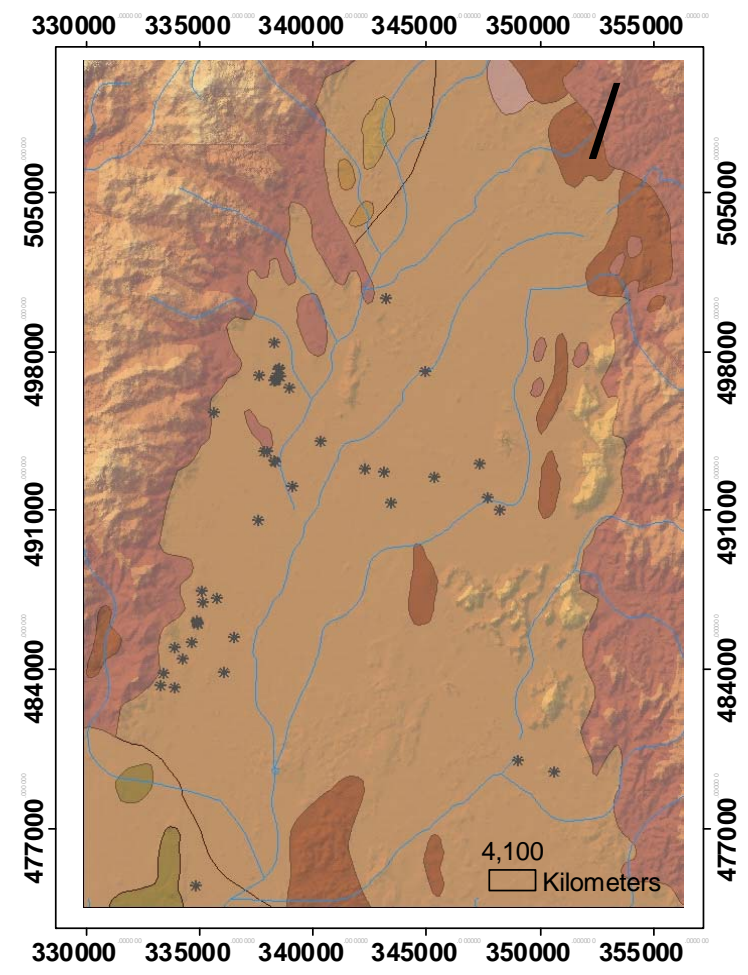

Figure 1. Location map of the study area.

best representation of the initial scene for clear visual presentation of the image and so improve its information content to the interpreter.

\subsection{Lineament Visual Extraction}

A reference map is required to validate the accuracy of the discontinuity map produced by automatic edge detection algorithms. In addition, to detect the non-geological lineaments such as roads with human eye [21]. Prior to image smoothing, the noise was eliminated by using an average low pass filter. Later, manual lineament extraction was performed. In this process, directional filtering method was applied for the lineament extraction. Directional nature method of Sobel kernels was applied on band 4 and this has generated an effective and faster way to evaluate lineaments in four principal directions [22].

\subsection{Digital Terrain Model (DTM) Generation}

DTM were derived using the SOCET TEM generation software from stereo-pairs of both Black-White and color scanned aerial photo. Image-matching techniques were used to locate conjugate points in the images and then determine the heights based on the image orientation data. The DTMs were generated for all areas of mining at a spatial resolution of $0.85 \mathrm{~m}$. Given the reliability of the GCPs used, an accuracy of $99 \%$ in relative height differences in stereo models was achieved. Ortho-images were then generated from the orientated Black-White and col- our images and the DTMs resampled at ground distance of $0.85 \mathrm{~m}$ to annotated grid spacing of $30 \mathrm{~m}$ as shown in Figure 2.

Once the TINs were created, their surface area characteristics were determined using ARC GIS 3D Analyst extension. The two first-order derivatives of elevation (slope measured in degrees, ranging from $0^{\circ}$ to $90^{\circ}$ ) and aspect measured in compass bearings, from $0^{\circ}$ to $360^{\circ}$ were easily calculated from the DTM in ArcGIS using the Spatial Analyst extension.

\subsection{Geo-Hazard Map Generation Method}

The production of sinkhole geohazard map requires summing the weightage of each hazard element. The preparation of the sinkhole geohazard map involved summing the weighted values for each hazard element, which permits the construction of: geohazard model. For this, the calculated and extracted factors were mapped into a $10 \mathrm{~m} \times 10 \mathrm{~m}$ grid in ARC/INFO GRID format. Next, using the weights-of-evidence method, spatial relationships between the landslide location and each of the landslide-related factors, soil distribution, the trends of major faults, sinkhole density, lithology, distribution of ponds and streams, main roads and highways and the distribution of slopes were analyzed. These themes were rastrized into GIS environment and supplied with weighted average.

The spatial relationships were used as each factor's rating in the overlay analysis. Subsequently, tests of conditional independence were performed for the selection of the factors to be used in landslide susceptibility mapping. The factors' ratings were summed to calculate a sinkhole susceptibility index, and sinkhole susceptibility was mapped for 8 combinations of the factors. Finally, the results of a comparison of the 8 different combinations were validated using sinkhole test location data.

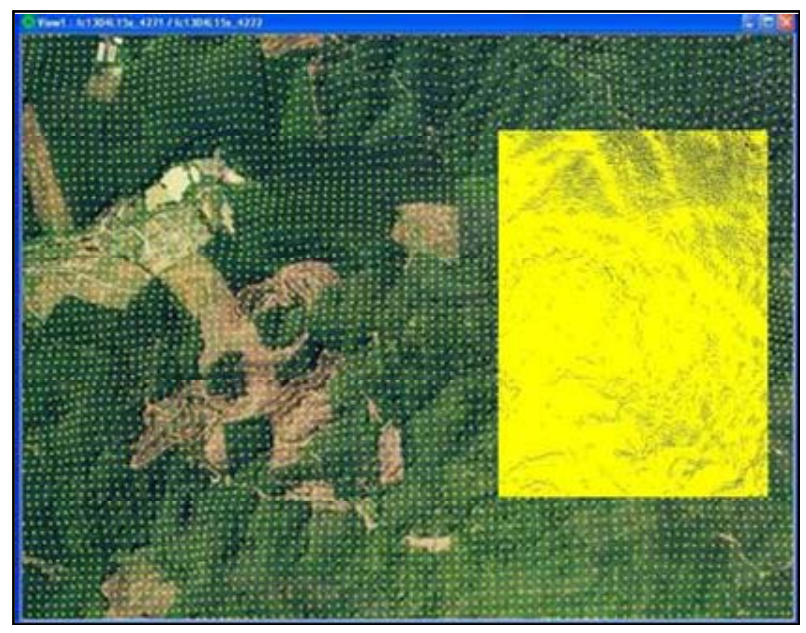

Figure 2. Typical grid point with XYZ generated from stereo-photo pairs. 
The contributed factors and their influence coefficients of sinkhole occurrence are tabulated in Table 1. As following:

Geospatial data can be presented either in raster or vector form. We have chosen to develop the sinkhole geo-hazard model as a raster model, because they are easier to manipulate and process. The calculation and determination of the sinkhole hazard map depend on the geospatial data presentation model (raster or vector) of its factors. The difference of these factors data model requires unification. Between the raster model and vector model, the raster data model are easy to manipulate and process compared with vector models. Thus, the output data model of the sinkhole geohazard map. The calculation unit of the raster data model is pixel $(P)$; where the pixel presents, in reality, a metric square. Each contributed hazard factor $(F)$ is expressed in matrix of pixels that present the raster model of that factor. Depending on the number of the factors $(n)$, the total contributed factors in geo-hazards map are $\sum F_{n}$; for each pixel of the sinkhole geo-hazard map. However, the contributed fac- tors have different influence. Thus, each factor $F_{n}$ have a coefficient $C_{n}$ that determine the influence level on sinkhole geo-hazard map. Therefore, the total contributed factors with it's' influence coefficients of sinkhole geohazard map for each pixel, $\left(\left|P_{\text {sinkhole.hazard }}\right|\right)$ is expressed as follows:

$$
\left|P_{\text {sinkhole.hazard }}\right|=\sum F_{n} \cdot C_{n}
$$

where $P=$ final value of the pixel on the model;

$F_{n}=$ value for that pixel of hazard factor $n$;

$C_{n}=$ influence level coefficient associated with $F_{n}$.

Each hazard element is assigned a weight and the presence or absence of the hazard element within the cell determines if that weight is added to the sum (Figure 3). We utilized the Model Builder in ArcGIS (Figure 4) to house the model. While the weighted sums are calculated as floating point variables, they were binned into ranges when inserted into the model's grid. These ranges represent ranks, and each rank is given an integer value. The higher values represent higher hazard levels. Each type of hazard will therefore have several rakes, depending on

Table 1. Weighting of controlling factors influence of hazard map.

\begin{tabular}{|c|c|c|c|}
\hline Raster data type and it main classes & Weighting & Raster data type and it main classes & Weighting \\
\hline 1) Sinkhole diameter & & 5) Water influence density map & \\
\hline $0-2$ & 1 & Ponds & 3 \\
\hline $2-5$ & 2 & Rivers & 3 \\
\hline $5-10$ & 3 & & \\
\hline$>10$ & 4 & & \\
\hline 2) Road density map & & 6) soil type & \\
\hline Cross roads & 1 & Serdang-Kedah & 1 \\
\hline T-junction & 2 & Holyrood-Lunas & 2 \\
\hline Main road & 3 & Mined land & 3 \\
\hline Urban area & 4 & Urban land & 4 \\
\hline 3)Avarage slope anagle & & 7) Geological map & \\
\hline$>10$ & 1 & Sandstone and limestone... act & 2 \\
\hline $10-25$ & 2 & Schist, salt with limestone & 3 \\
\hline $26-50$ & 3 & Limestone/marble & 4 \\
\hline$>50$ & 4 & & \\
\hline 4) Landuse vulnerability to sinkholes & & 8) Faults density map & \\
\hline Forest & 1 & Discountiued faults & 1 \\
\hline Agriculture & 2 & Faults cross roads & 2 \\
\hline Mining area & 3 & Faults cross water bodies. & 3 \\
\hline Urban area & 4 & Faults beside Granite & 4 \\
\hline
\end{tabular}




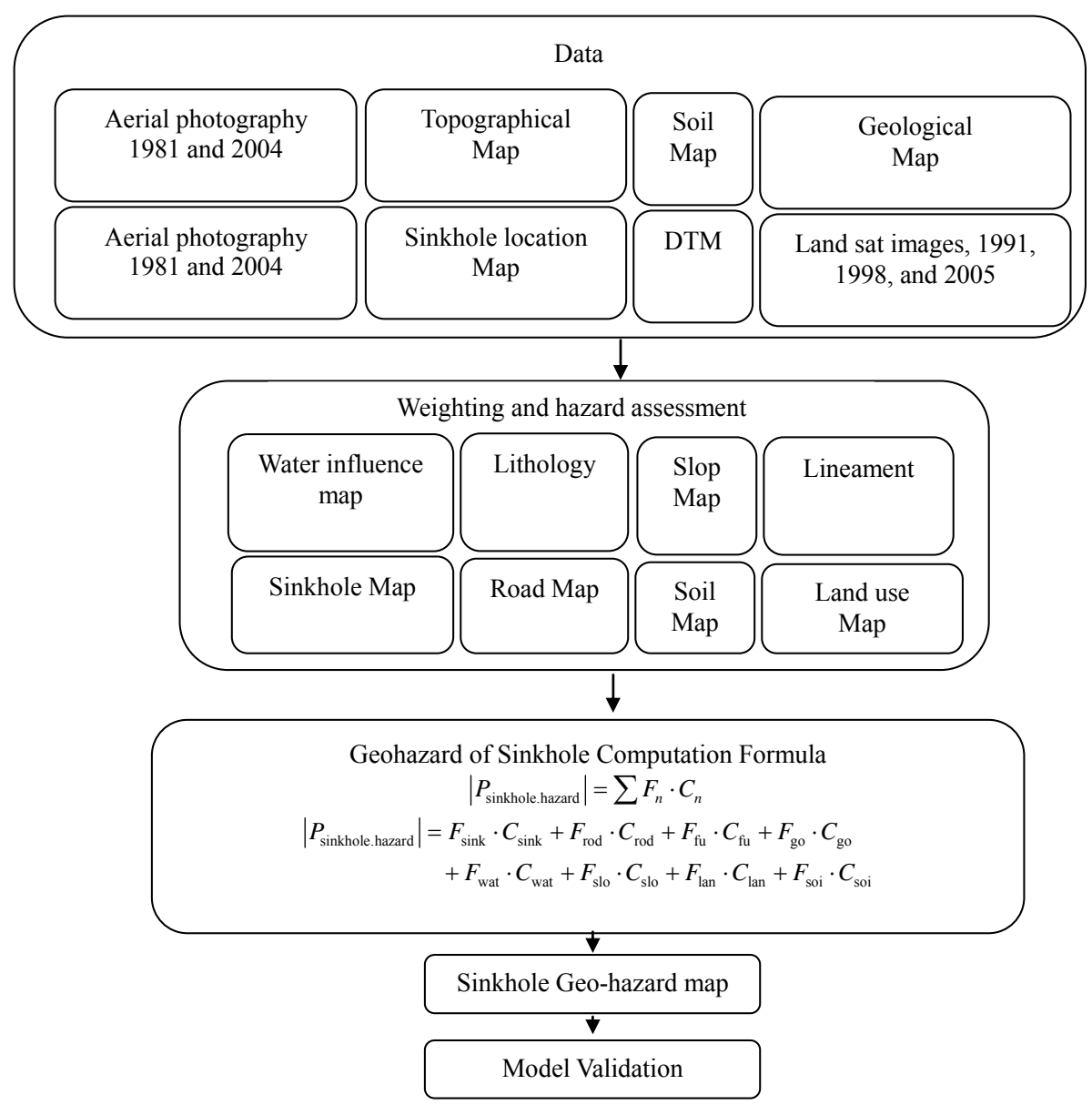

Figure 3. Components of the sinkhole susceptibility method.

the specifics of that hazard type. For example, slopes are divided into four ranks; those with the lowest gradients have the value of " 1 ", and the highest gradients have the value "4". The model was built by making criteria tree, where the conditioning parameter maps are grouped, standardized and weighted.

\section{Results and Analysis}

\subsection{Geo-Hazard Map in the Kinta Valley}

The most important factor of the geo-hazard map construction is the spatial distribution of sinkholes occurrence. Investigation on the history of sinkholes occurrence, urban development, faults distribution and ex mining ponds are factors that are directly responsible on all sinkholes and land subsidence hazards. Most of sinkholes concentrated on the northwest across the urban areas and west along the granite-limestone contact as well as the area further south of Kinta Valley as shown Figure 5. The waste chemical ponds of ex-mining, the main streams, the vibration and noise of high ways roads that cross the hazards area are the possible factors found to indicate the highest number of sinkholes occurrence.
Surface mining and sinkholes occurred in the past and will be developed in the future. The south and southwest of the study area is characterized by low slope rate varying from $0^{\circ}$ to $10^{\circ}$. This indicates slow ground water movement and probable low erosion (dissolution) in the limestone and more stability except in the locations of ex-mining.

Geological lineaments in terms of faults, joints and fractures, slope variation of limestone, sinkholes intensity, water table variation and urban distribution are significant parameters for the construction and the scoring of each location in geo-hazard map. The classification and the zoning of geo-hazard maps could be used as geotechnical reference for geologist and geotechnical engineers to identify the crucial location of high karst and dissolution rate as well as the buried sinkholes that could lead to unpredictable earth surface collapse.

Geo-hazard map has a vital role of sinkholes studies and management especially in area under laid of very sensitive carbonate rocks such as limestone and dolomite (Figure 5). In addition, it exposed to extreme high intensive urbanization and ex-mining activities. Figure 6 represents a geo-hazard model tool for sinkholes based 


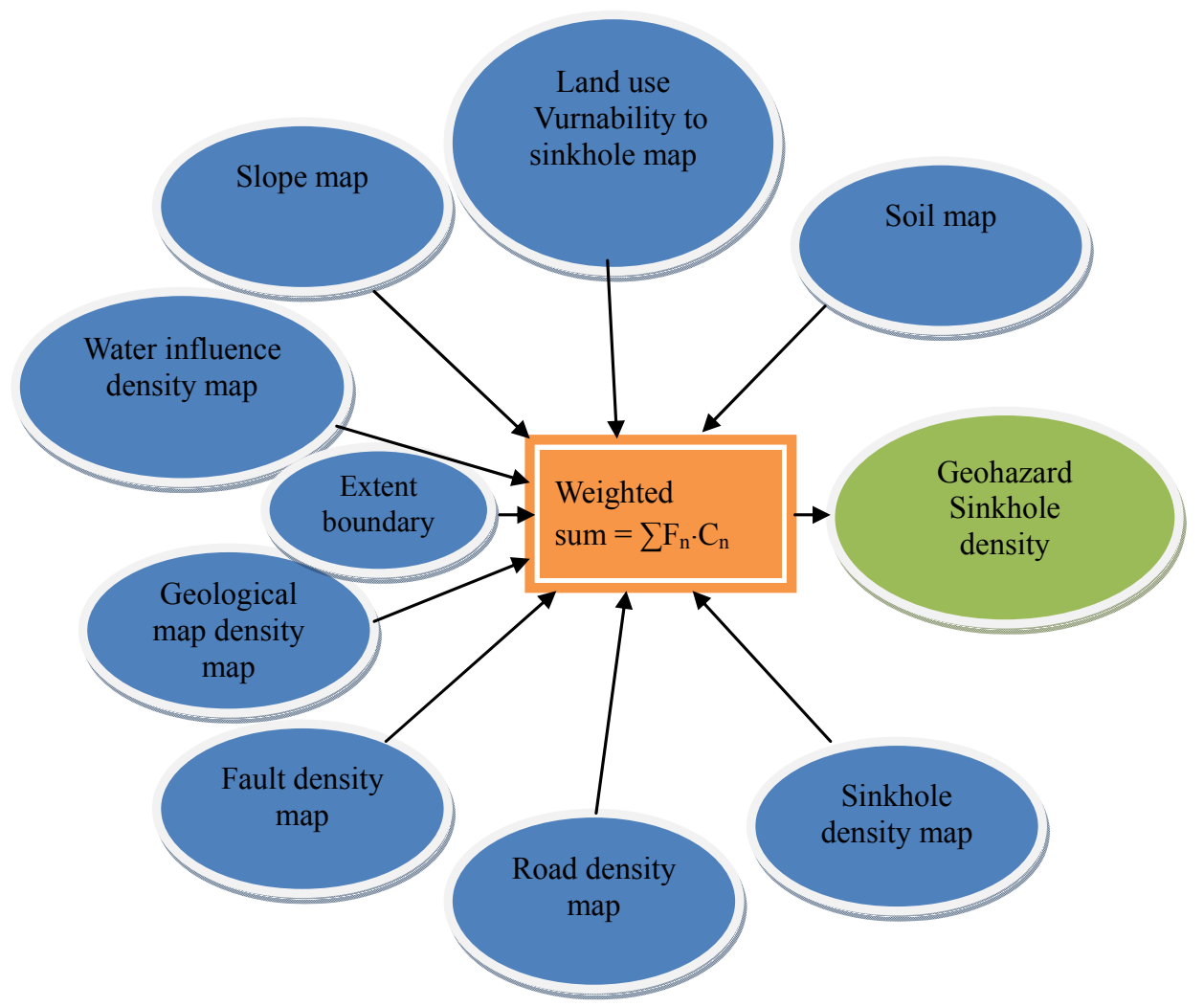

Figure 4. A GIS-geoprocessing model for geohazard sinkhole map.

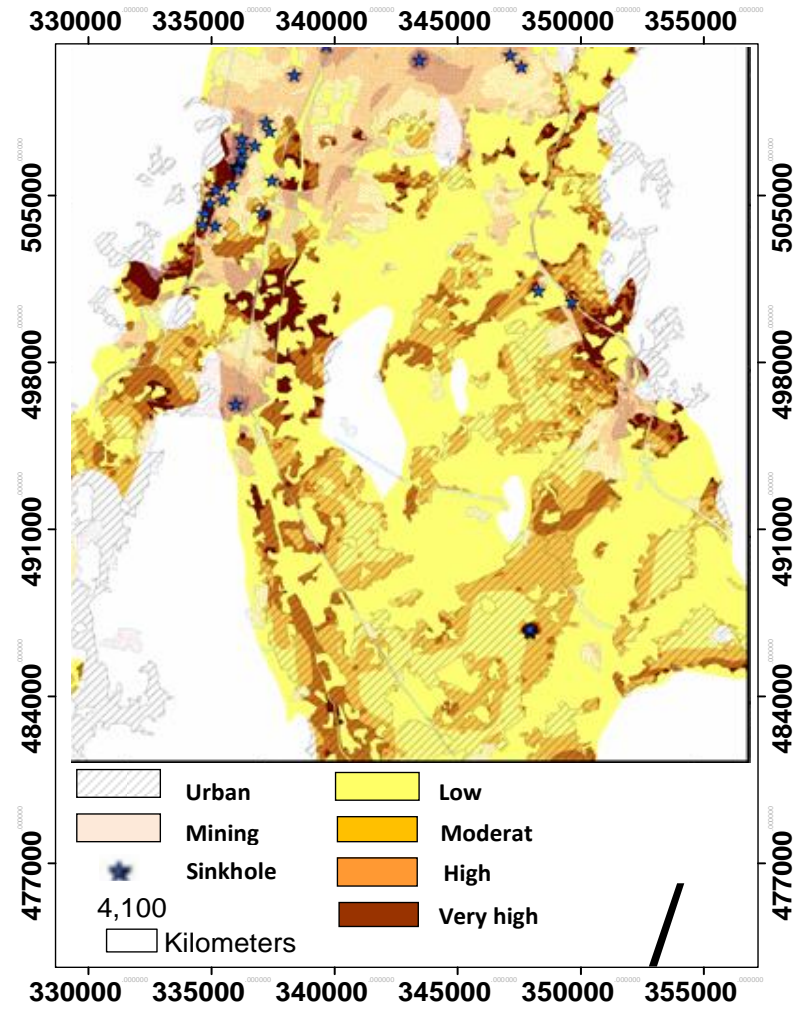

Figure 5. The overlay of mining and urban areas to form a geo-hazard map for the Kinta Valley.

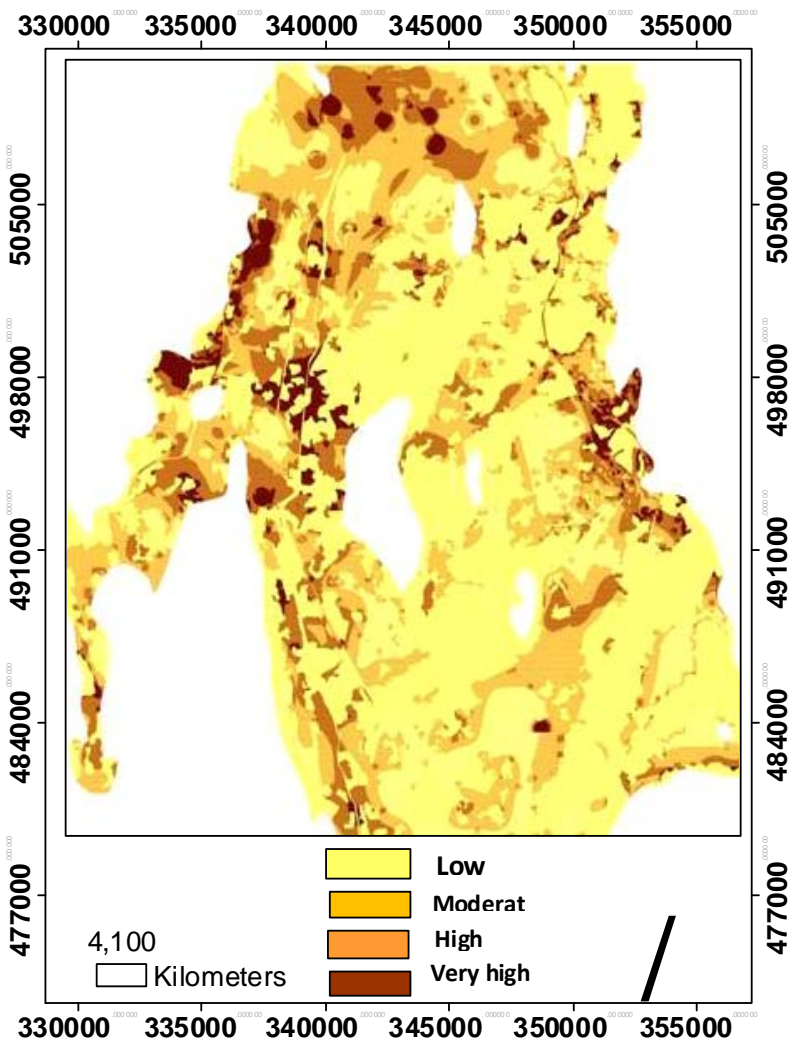

Figure 6. Geo-hazard map in the Kinta Valley. 
on contributed factors and hazards densities maps. This map was classified into four categories:

\subsubsection{Low Potential Hazard Areas}

There is only one sinkhole observed on the map having low probability for sinkhole development. The low potential hazard areas characterized of low slope varying from $0^{\circ}$ to $10^{\circ}$, less of human, less streams, mining/exmining and agriculture activities. These areas actually extend from east to further south of Kinta Valley. One sinkhole recorded in these areas during last decades (Table 2).

\subsubsection{Moderate Potential Hazard Areas}

Containing only widely scattered individual sinkholes or isolated clusters of two or three sinkholes, these areas have moderate probability to sinkholes, earth subsidence/ collapse and even rock failure occurrence. These however, specified of low slope varies between $0^{\circ}$ to $10^{\circ}$, quite number of streams and moderate urban development distributed in the north such as Ipoh city and south. This class covers most of the study area of weighted average of sinkholes. These areas beside the low potential hazard areas could be recommended from authorities for further small buildings, planimetric elements and agriculture.

\subsubsection{High Potential Hazard Area}

The high potential hazard areas which include steep slope varies from $10^{\circ}$ to $20^{\circ}$, intense streams, high density fractures, high urbanization and ex mining activities as well as ponds and lakes distribution. These areas lie adjacent to granite ridges in the East-West and North of Kinta Valley. It shows many sinkholes and earth subsidence throughout the last two decades.

The high ways noise and vibrations in conjunction with streams/ponds distributions found to be responsible of Jeram Village sinkholes and local earthquake occurrence in the south east of Kinta Valley. Furthermore the location of the study area near to ring of fire along Sumatra has directly influenced the development and occurrence of sinkholes especially further south of Kinta
Valley far from granite ridge protection.

\subsubsection{Very High Potential Hazard Areas}

The crucial sites within the study area are located in the North, North-East and North-West especially near granite ranges (limestone/granite contact) and high urban areas as well as the ex-mining areas in terms of ponds and lakes. In other words, Close to the very steep slope areas, the intersection of river and faults with ponds and urban areas are factors control most of the very high potential hazard areas of weighted average. An important number of sinkholes recorded and documented along high ways and industrial areas along the limestone-granite contact for example, Bukit Merah exposed to 21 sinkholes and earth surface subsidence during the period from 1981 to 1998 . These types of areas must be categorized as restricted areas for new and long towers constructions.

\subsection{Validation of the Geo-Hazard Maps}

The accuracy of the hazard map was evaluated by comparing the hazard map extracted from the model with actual ground observations. The recorded Global Positioning Satellite (GPS) data was added to the hazard map to validate its accuracy. It was found that twenty (20) elements were located in their proper potential hazard class (Table 3).

To validate the model of potential hazard of sinkhole occurrence we inspected twenty one ground truths. Ten locations of the actual field observation are located within the high potential hazard areas, and seven locations are located within very high potential hazard areas. Figure 7 shows the resulting Geohazard Map and the locations of actual hazard based on sinkholes location in high and very high potential hazard areas. It can be concluded that the accuracy of the model is about $95 \%$ for the hazard area based on field observation location and report from The Malaysian Geological and Mineral Department. However, field observations, ground truths and geophysical data in Bukit Merah Village found that four locations of ground truth are located within very high potential hazard area (Figure 7).

Table 2. Percentage area of geo-hazard map classification.

\begin{tabular}{|c|c|c|c|c|c|}
\hline Geo-hazard map classification & Area $\%$ & Sinkholes Number & Sinkhole\% & Diameters (m) & Remarks \\
\hline Low risk areas & 53.5 & 1 & 1.7 & $0-2$ & No activities or urbanization area \\
\hline The moderate risk areas & 32.4 & 3 & 5.3 & $2-5$ & Beside Limestone hills, Ipoh town \\
\hline The high risk area & 8.6 & 12 & 21.1 & $5-10$ and $>10$ & $\begin{array}{l}\text { Jeram, Bikit Merah, } \\
\text { Mining area, Ipoh town }\end{array}$ \\
\hline Total & 100 & 57 & 100 & & \\
\hline
\end{tabular}


Table 3. Location of ground truths-observations in Kinta Valley.

\begin{tabular}{|c|c|c|c|c|}
\hline \multirow{2}{*}{$\begin{array}{c}\text { No. } \\
1\end{array}$} & \multirow{2}{*}{$\frac{\text { Area name }}{\text { Air Panas }}$} & \multicolumn{2}{|c|}{ Location of ground truths observation } & \multirow{2}{*}{$\begin{array}{c}\text { Geohazard level map } \\
\text { The high risk area }\end{array}$} \\
\hline & & N432.496 & E101 02.226 & \\
\hline 2 & Bukit Merah & N437.148 & E101 08.763 & Very high risk areas \\
\hline 3 & Bukit Merah & N434.602 & E101 03.800 & Very high risk areas \\
\hline 4 & Sg.Anak Ayer Cina & N440.071 & E101 11.628 & The high risk area \\
\hline 5 & Cemetery & N437.532 & E101 09.165 & Very high risk areas \\
\hline 6 & Choo Seng & N435.043 & E101 09.733 & Very high risk areas \\
\hline 7 & Sg.Kinta Empangan & N433.307 & E101 07.774 & The high risk area \\
\hline 8 & Giant & N440.209 & E101 11.913 & The Moderate Risk Areas \\
\hline 9 & Intim Sg.Pinjih & N440.104 & E101 09.442 & The high risk area \\
\hline 10 & Kambing Ulu Piah & N434.084 & E101 06.838 & The high risk area \\
\hline 11 & KLT-B & N437.141 & E101 09.503 & Very high risk areas \\
\hline 12 & KLT-K & N431.001 & E101 08.286 & Very high risk areas \\
\hline 13 & Sg.Kinta Korbu & N436.446 & E101 05.056 & The high risk area \\
\hline 14 & Masjid Sg.Kinta & N435.896 & E101 04.754 & The Moderate Risk Areas \\
\hline 15 & Perodua & N436.580 & E101 08.326 & Very high risk areas \\
\hline 16 & Petronas & N4 32.018 & E101 08.211 & The high risk area \\
\hline 17 & Pond Tambun & N4 36.866 & E101 08.658 & Very high risk areas \\
\hline 18 & Sg Raia Kuil & N4 31.764 & E101 08.410 & The Moderate Risk Areas \\
\hline 19 & Sg.Bukit Merah 1 & N4 38.847 & E101 10.980 & Very high risk areas \\
\hline 20 & Sg.Bukit Merah 2 & N4 34.258 & E101 03.253 & Very high risk areas \\
\hline
\end{tabular}

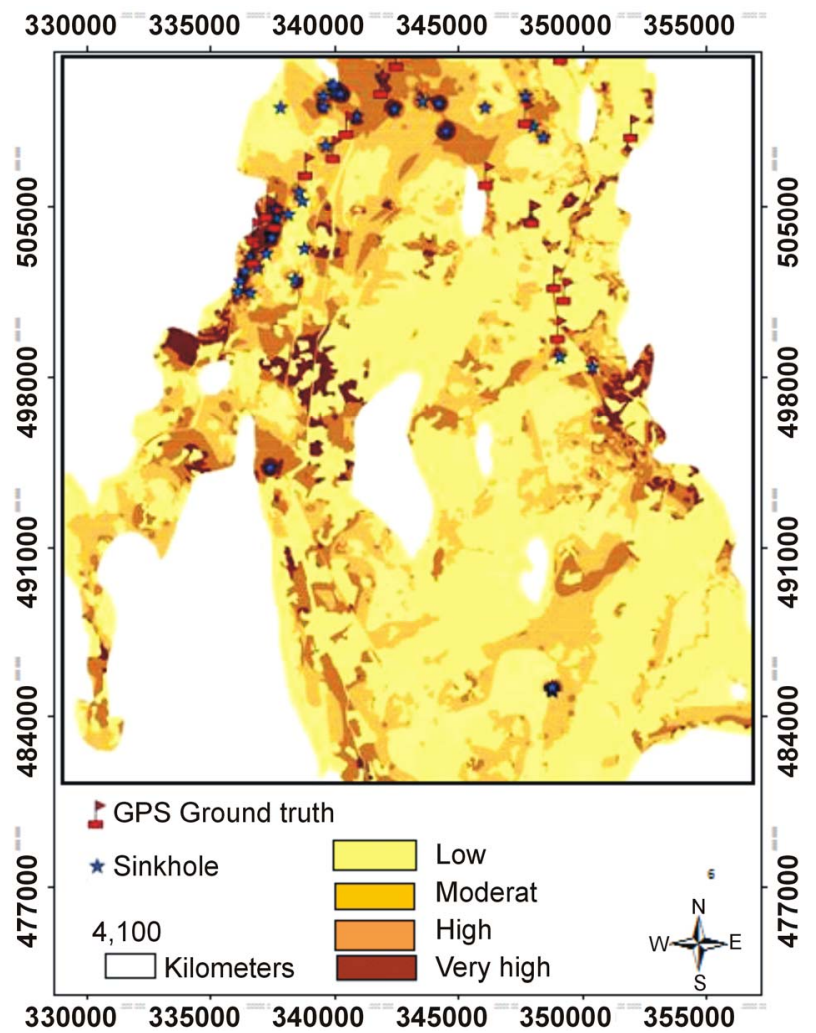

Figure 7. Geohazard map validation in the Kinta Valley.

\section{Conclusion}

- Sinkholes are the most serious geological hazard in karst terrains. It is formed as a result of a sudden collapse of the overlying soil into a depression with steep to sub-vertical sides. Occasionally, a sinkhole is a funnel-shaped or bowl-shaped depression and sometimes it is circular. The size of a sinkhole may vary in diameter from as small as $1 \mathrm{~m}$ to as large as $30 \mathrm{~m}$.

- The study area has abundant karst features, resulting from various factors such as rapid urban-industrial developments, ex-mining activities and intense rainfall on hilly areas.

- GIS and Remote Sensing were used to address information extraction, database establishment and model development.

- The use of GIS model facilitated these updates. Microsoft Access and GIS software were used to develop the database application tools for data input. This helps the creation of a hazard map based on sinkholes distribution and controlling factors.

- Geospatial technologies were found to be quantitative analysis of hazard map for sinkholes distribution with multi thematic layers compared to current method of sinkholes data organization based on papers, articles and reports, which were converted to digital format to 
be processed in GIS.

- Quantitative sinkhole hazard (probability) allows assessing the potential damage that may be caused by sinkholes hazard and performing cost-benefit analysis.

\section{REFERENCES}

[1] A. Klimchouk, "Morphogenesis of Hypogenic Caves," Geomorphology, Vol. 106, No. 1-2, 2009, pp. 100-117. http://dx.doi.org/10.1016/i.geomorph.2008.09.013

[2] R. Brinkmann, M. Parise and D. Dye, "Sinkhole Distribution in a Rapidly Developing Urban Environment: Hillsborough County, Tampa Bay Area, Florida," Engineering Geology, Vol. 99, No. 3-4, 2008, pp. 169-184. http://dx.doi.org/10.1016/j.enggeo.2007.11.020

[3] M. Parise, J. De Waele and F. Gutiérrez, "Current Perspectives on the Environmental Impacts and Hazards in Karst," Environmental Geology, Vol. 58, No. 2, 2009, pp. 235-237. http://dx.doi.org/10.1007/s00254-008-1608-2

[4] F. Gutierrez, A. H. Cooper and K. S. Johnson, "Identification, Prediction, and Mitigation of Sinkhole Hazards in Evaporite Karst Areas," Environmental Geology, Vol. 53, No. 5, 2008, pp. 1007-1022. http://dx.doi.org/10.1007/s00254-007-0728-4

[5] Y. Gao and E. C. Alexander, "Sinkhole Hazard Assessment in Minnesota Using a Decision Tree Model," Environ Geol Springer-Verlag Environmental Geology, 2008.

[6] A. Bahtuarevic, "Sinkhole Density of the Forest City Quadrangle: Proceeding of 3rd Multidisciplinary Conference on Sinkholes," PELA Barbados 1:2500 (Cartography) (1977), Ministry of Overseas Department, British Government, St. Petersburg Beach, 1989.

[7] A. Al Zoubi, A, Abueladas, R. Al Rzouq, C. Camerlynck, E. Akkawi, Z. S. H. Abu-Hamattah, W. Ali and B. S. Al Rawashdeh, "Use of 2D Multi Electrodes Resistivity Imagining for Sinkholes Assessment along the Eastern Part of the Dead Sea," Science Publication, American Journal of Applied Science, 2007.

[8] Y. Gao and E. C. Alexander, "Sinkhole Hazard Assessment in Minnesota Using a Decision Tree Model," Environmental Geology, Vol. 54, No. 5, 2007, pp. 945-956. http://dx.doi.org/10.1007/s00254-007-0897-1

[9] J. A. Green, W. J. Marken, E. C. Alexander Jr. and S. C. Alexander, "Karst Unit Mapping Using Geographic Information System Technology, Mower County, Minnesota, USA," Environmental Geology, Vol. 42, No. 5, 2002, pp. 457-461.

http://dx.doi.org/10.1007/s00254-001-0505-8

[10] D. A. Hubbard, "Use of Regional Sinkhole Mapping for Sinkhole Susceptibility Maps, 2003," Sinkholes and the Engineering and Environmental Impacts of Karst, Geotechnical Special Publication No. 122, 2003, pp. 61-71.
[11] A. Rawashdeh, R. Ruzouq, A. Al-Fugara, B. Pradhan, S. H. Abu-Hamatteh Ziad and A. R. Ghayda, "Monitoring of Dead Sea Water Surface Variation Using Multi-Temporal Satellite Data and GIS," Araabien Journal of Geosciences, 2012, 8 p.

[12] Y. Gao and E. C. Alexander, "Application of GIS Technology to Study Karst Features of South-Eastern Minnesota," In: Beck \& Herring, Eds., Geotechnical and Environmental Application of Karst Geology and Hydrology, Swets \& Zeitlinger, Lisse, 2001.

[13] Y. Gao, "Karst Feature Distribution in Southeastern Minnesota: Extending GIS-Based Database for Spatial Analysis and Resource Management," Ph.D. Thesis, University of Minnesota, 2002.

[14] T. Waltham, F. Bell and M. Culshaw, "Karst and Cavernous Rocks in Engineering and Construction," Springer Praxis Books Geophysical Sciences, 2004.

[15] A. AlFugura, L. Billa and B. Pradhan, "Semi-Automated Procedures for Shoreline Extraction Using Single Radarsat-1 SAR Image," Estuarine, Coastal and Shelf Science, Vol. 95, No. 4, 2011, pp. 395-400. http://dx.doi.org/10.1016/j.ecss.2011.10.009

[16] P. Biswajeet and P. Saied, "Comparison between Prediction Capabilities of Neural Network and Fuzzy Logic Techniques for Landslide Susceptibility Mapping," Disaster Advances, Vol. 3, No. 2, 2010, pp. 26-34.

[17] S. Pirasteh, B. Pradhan and S. M. Rizvi, "Tectonic Process Analysis in Zagros Mountain with the Aid of Drainage Networks and Topography Maps Dated 1950-2001 in GIS," Arabian Journal of Geosciences, Vol. 38, No. 4, 2011, pp. 171-180. http://dx.doi.org/10.1007/s12517-009-0100-y

[18] D. A. Hubbard, "Sinkhole Distribution of the Valley and Ridge Province, Virginia," Geotechnical and Environmental Applications of Karst Geology and Hydrology, 2001, pp. 33-36.

[19] A. C. Waltham and P. G. Fookes, "Engineering Classification of Karst Ground Conditions," Quarterly Journal of Engineering Geology and Hydrogeology, Vol. 36, No. 2, 2003, pp. 101-118. http://dx.doi.org/10.1144/1470-9236/2002-33

[20] C. Denizman, "Morphometric and Spatial Distribution Parameters of Karstic Depressions, Lower Suwanee River Basin, Florida," Journal of Cave and Karst Studies, Vol. 65 , No. 1, 2003, pp. 29-35.

[21] R. F. Muhammad and Y. Ee Beng, "Potential Conservation on Some Important Karst Sites in the Kinta Valley and Lenggong: A Preliminary Study," In: D. I. Komoo and M. S. Leman, Eds., Warisan Geologi, Malaysia, 2001.

[22] A. Mah, G. R. Taylor, P. Lennox and L. Balia, "Lineament Analysis of Landsat Thematic Mapper Images, Northern Territory, Australia," Photogrammetric Engineering and Remote Sensing, Vol. 61, No. 6, 1995, pp. 761-773. 